\section{MEETINGS AND COURSES}

\section{Throughout 2001}

Title. New concepts in contraception, HRT and all aspects of sexual and reproductive health care. Venue. Margaret Pyke Memorial Trust. Details. Advanced classes through 2001 in new concepts in contraception and sexual and reproductive health care. Please see our display advertisement for further details. Information. Heather Goodman, The Margaret Pyke Centre, 73 Charlotte Street, London, W1T 4PL. Tel: 020 7436 8390, Fax: 0207580 2495, email: mpmt@hotmail.com.

\section{February 26th 2001}

Title. British Menopause Society - nurses study day. Venue. Manchester Conference Centre, Weston Building. Details. This meeting entitled 'Practical aspects of menopause management for nurses' will cover: memory, Alzheimer's and the menopause, dealing with side effects, osteoporosis, breast cancer risks, are there realistic alternatives to HRT?, putting it all into practice and an open forum for your questions. Information. British Menopause Society, 36 West Street, Marlow, Bucks, SW7 2NS. Tel: 01628 890199, Fax: 01628474 042, email: britishmenopausecociety@ compuserve.com.

\section{February 28th - March 2nd 2001}

Title. Theoretical training course for the diploma in family planning and reproductive health care. Venue. Educational Centre, Pinderfield Hospital, Wakefield. Details. Theoretical family planning course for GPs and GP registrars. Faculty of Family Planning accredited, GP CME accreditation. Information. Jenny Scott, PGMC Pinderfield Hospital, Aberford Road, Wakefield, WF1 4DG. Tel: 01924 212263, Fax: 01924 814546 .

\section{March 3rd 2001}

Title. NW Society of Sexual Medicine and Family Planning Spring meeting. Venue. Maritime Museum, Albert Dock, Liverpool, UK.
Details. Will include talks on: the future of ovarian disease, Chinese medicine in women's health, chronic pelvic pain, coils - where are we now? and a question and answer session with various scenarios. Information. Mavis $\mathrm{L}$ Barnard, 7 Regent Road, Chorley, PR7 2DH, UK. Tel: 01257267657.

\section{March 3rd 2001}

Title. The 109th meeting of the Northern Interbranch Doctors' Group. Venue. East Riding Medical Education Centre, Hull Royal Infirmary, Anlaby Rd, Hull, UK. Details. A oneday update for members and guests on reproductive and sexual health. PGEA, CME and Faculty accreditation applied for. Information. Dr Gillian Wight, Roulston Cottage, Sutton-under-Whitestonecliffe, Thirsk, North Yorkshire, YO7 2PS, UK. Tel: 01845 597329

\section{March 14th and 15th 2001}

Title. Two-day basic theoretical course in family planning and reproductive health care. Venue Blair Bell Conference Centre, Liverpool Women's Hospital NHS Trust, Crown Street, Liverpool. Details. This course can also be attended for updating doctors and nurses. Information. Carmel Farrell, University of Liverpool, Mersey Region Group for Family Planning Training, Department of Obstetrics and Gynaecology, Liverpool, L69 3BX. Tel: 0151 7024102 (Monday - Friday 9:00 am to 3:00 pm), Fax: 0151702 4039, email: carmelfarrell@yahoo.com.

\section{March 22nd and 23rd 2001}

Title. Basic course for the diploma of the faculty of family planning and reproductive health care. Venue. Regents College, Regents Park, London, NW1 4NS. Details. Organised by John Guillebaud, Professor of family planning and reproductive health. Other dates in 2001: May 31 st and June 1 st, October 4th and 5th, December 13th and 14th. First part of DFFP and PGEA accreditation. Information. Dawn Atkinson, Margaret Pyke Centre, 73 Charlotte Street, London, W1T 4PL. Tel: 02075303608 , Fax: 02075303646.

\section{April 26th 2001}

Title. Annual doctors and nurses family planning update day. Venue. Park Royal International Hotel, Warrington, Cheshire. Details. Registration $£ 80$ for doctors, $£ 65$ for nurses. 9:00 am to 4:00 pm. PGEA and Faculty of Family Planning approved. Information. Carmel Farrell, University of Liverpool, Mersey Region Group for Family Planning Training, Department of Obstetrics and Gynaecology, Liverpool, L69 3BX. Tel: 01517024102 (Monday - Friday 9:00 am to 3:00 pm), Fax: 0151702 4039, email: carmelfarrell@yahoo.com.

\section{May 9th, 10th and 11th 2001}

Title: Theoretical diploma course in family planning and reproductive health care. Venue. Post Graduate Centre, Gloucestershire Royal Hospital. Details. Organised by Severn NHS Trust and East Gloucestershire NHS Trust. PGEA and FFPRHC accreditation to be applied for. Information. Jenny Livingston, Family Planning, Hope House, Gloucestershire Royal Hospital, Great Western Road, Gloucester, GL1 3NN, UK. Tel: 01452 394962, Fax: 01452 394808.

\section{May 12th and 13th 2001}

Title. Weekend family planning theory course for doctors. Venue. Northwick Park Hospital, Harrow, Middlesex. Details. Theoretical component for the DFFP suitable for continuing professional development, Faculty recertification and RCOG CME. Faculty and PGEA approvals applied for. Information. Diane Price, Family Planning Training Officer, Level 6 Maternity Block, Northwick park Hospital, Watford Road, Harrow. Tel: 0208869 3127, Fax: 02088692903.

There is now a charge of $£ 50+$ VAT for
each meeting/course publicised in the
Meetings and Courses column of the
Journal. This will guarantee inclusion in
the issue requested. For further
information please contact Sarah Monger
at PMH Publications, PO Box 100,
Chichester, West Sussex, PO18 8HD, UK.
Tel: +44 (0)1243 576444; Fax: +44 (0)1243
576456 ; email:adsales@pmh.uk.com.

There is now a charge of $£ 50$ + VAT for Journal. This will guarantee inclusion in the issue requested. For further information please contact Sarah Monger 576456; email:adsales@pmh.uk.com. 